Article

\title{
Physicochemical Properties and Lignin Degradation of Thermal-Pretreated Oil Palm Empty Fruit Bunch
}

\author{
Intan Nazirah Mohammad, Clarence M. Ongkudon and Mailin Misson *(i) \\ Biotechnology Research Institute, Universiti Malaysia Sabah, Jln UMS, Kota Kinabalu 88400, Sabah, Malaysia; \\ intannazirah0394@gmail.com (I.N.M.); clarence@ums.edu.my (C.M.O.) \\ * Correspondence: mailin@ums.edu.my; Tel.: +60-88-320991
}

Received: 21 September 2020; Accepted: 28 October 2020; Published: 16 November 2020

\begin{abstract}
Oil palm empty fruit bunches (EFB) are recoverable lignocellulosic biomass serving as feedstock for biofuel production. The major hurdle in producing biofuel from biomass is the abundance of embedded recalcitrant lignin. Pretreatment is a key step to increase the accessibility of enzymes to fermentable sugars. In this study, thermal pretreatments at moderate temperatures ranging from $150{ }^{\circ} \mathrm{C}$ to $210^{\circ} \mathrm{C}$, at different durations (30-120 min) and EFB particle sizes (1-10 mm), were employed to maximize lignin degradation. Observation through a scanning electron microscope (SEM) revealed disruptions in EFB structure and the removal of silica bodies and other impurities upon thermal pretreatment. Remarkable changes on the elemental contents and functional groups occurred, as was evident from the energy dispersive X-ray (EDX) and Fourier transform infrared (FTIR) analyses. The smallest EFB size yielded higher lignin degradation-about 2.3-fold and 1.2-fold higher-than the biggest and moderate tested EFB sizes, indicating a smaller particle size provides a higher surface area for bioreaction. Furthermore, applying a longer duration of treatment and a higher temperature enhanced lignin degradation by up to $58 \%$. This study suggests that moderate thermal treatment could enhance lignin degradation by altering the physicochemical structure of $\mathrm{EFB}$, which is beneficial in improving biofuel production.
\end{abstract}

Keywords: oil palm empty fruit bunch; lignin degradation; physicochemical; thermal pretreatment; biofuel production

\section{Introduction}

The processing of oilseeds by the palm oil industry stimulates great socioeconomic impact. The success of the oil palm industry brought to the national economy about RM 67.6 billion in export earnings in 2016, which equals $6.1 \%$ of Malaysia's total GDP [1]. As the second largest palm oil producer worldwide, Malaysia contributes about $37 \%$ of the global market [2]. The massive production of oil palm has consequently resulted in a tremendous accumulation of huge amounts of agricultural wastes, such as oil palm trunks, oil palm fronds, empty fruit bunch (EFB) and palm pressed fibers [3], by the industry. According to Roslan and Zakaria [4], only 10\% of palm oil is extracted from fresh palm fruit bunches, while the remaining $90 \%$ is discarded. Burning biomass wastes may cause emissions of greenhouse gases, while dumping them into plantation sites for natural decomposition may create homes for pests [5]. As such, the conversion of biomass wastes into commercially valuable products has been of biotechnological interest.

EFB is a lignocellulose material made up of cellulose (20-50\%), hemicellulose (23-36\%), lignin and other derivatives (22-51\%) [6]. An interesting fact is that cellulose and hemicellulose are made up of various fermentable sugars that can be converted into biofuel [7]. Different biomass substrates possess different lignocellulosic contents. According to Rambo and Schmidt [8] sugarcane baggase possess a high cellulose content, determined at $43.3 \%$, in comparison with rice husks $(31 \%)$, pine wood $(36.5 \%)$ 
and corncob (30.2\%). Meanwhile, the hemicellulose components of corncob is 1.3-fold and 1.7-fold higher than rice husks and pine wood, respectively. Lignin is an amorphous polymer imparting structural integrity to EFB cell walls. Lignin is composed of phenylpropane units comprising guaiacyl alcohol (G), syringyl alcohol (S) and $p$-coumaryl alcohol $(\mathrm{H})$. The interunits are linked together by several covalent bonds, such as aryl-ether, aryl-aryl carbon-carbon bonds $[9,10]$. Besides lignin, the presence of silica bodies on the EFB surface also hinders the penetration of biochemicals into the hemicellulose and cellulose matrix. These highly complex structures and strong chemical bonds make the conversion of cellulosic materials into bioethanol challenging. The physicochemical structures of biomass hinder the hydrolysis of celluloses present in biomass due to their complexity and variability [11]. The disruption of the physicochemical structures via pretreatment could increase the rate of hydrolysis 3- to 10-fold [12]. According to Muhammad Nauman Aftab [12], the pretreatment of lignocellulose material is a vital step to facilitate the breaking of strong linkages of polymers within the plant cell wall, thus increasing their availability for enzymatic reactions, digestibility and product yield. Therefore, the pretreatment of the recalcitrant feedstocks should be employed to resolve these limitations.

In order to break the polymeric network of lignin, several methods have been employed to disrupt the lignocellulosic structure of biomass, including chemical, biological and physical pretreatments. The aim of the pretreatment strategies is to enhance the enzymes' or acids' accessibility to hydrolyze cellulose through the breaking of lignin structures, as well as disrupting the crystalline structure of cellulose [13]. The usage of alkaline or acid chemicals in chemical pretreatment unfortunately causes toxic accumulation and environmental damages [14,15]. Biological pretreatment offers an environment-friendly pathway by utilizing bacterial and fungal enzymes [16,17]; however, the expensive processes of enzyme production and purification have been recognized as the major hurdle for large-scale application [9]. Physical pretreatment, on the other hand, has received great attention as an efficient technology for the reduction of lignocellulose recalcitrance and component separation. In addition, this technology is environmentally friendly as it does not any hazardous chemicals. Moreover, it requires a shorter treatment duration.

In this regard, the technology could be used as a green and feasible approach, which normally involves thermal treatment, such as pyrolysis, hydrogenolysis and hydrolysis, of lignin with or without catalysts. The technical aspects and process viability should be considered so as to maximize the economic benefits and mimic actual industrial practice. While the aim is to obtain highly accessible lignocellulosic for hydrolysis and achieve a higher production of fine sugars, the pretreatment process should avoid the degradation of the desired fermentable sugars. Oil palm EFBs have been treated with various approaches, including hydrothermal treatment [3], steam or superheated steam [18,19], subcritical phenol [2], ball milling pretreatment and diluted acid hydrolysis [20], and Fenton oxidation with $\mathrm{Fe}(\mathrm{III}), \mathrm{Fe}(0)$ and $\mathrm{Fe}_{3} \mathrm{O}_{4}$ as a catalyst [21]. Under the effect of temperature, lignin degradation occurs due to chemical reactions, as a result of which the physical structure evolves [22]. Lignin acts as an amorphous thermoplastic polymer, which develops a rubber-like structure upon being heated beyond its glass transition temperature, which allows some structural movement [23]. Lignin would lose these thermo-plasticity properties upon harsh treatment, which causes severe degradation in its high molecular weight and three dimensional structure [11].

As such, in the present study, thermal treatment at varying conditions was investigated to enhance lignin degradation in the EFB structure. The chosen pretreatment method can be accomplished in a shorter period of time, and could alter the structural composition of EFB more effectively than the biological method. The aim of this study was to investigate the effect of the thermal treatment on the physicochemical structure of EFB and the degradation of the lignin structure. The treatments were conducted at different temperatures $\left(150^{\circ} \mathrm{C}, 170^{\circ} \mathrm{C}, 190^{\circ} \mathrm{C}, 210^{\circ} \mathrm{C}\right)$, pretreatment durations $(30 \mathrm{~min}$, $60 \mathrm{~min}, 90 \mathrm{~min}, 120 \mathrm{~min}$ ) and EFB sizes ( $1 \mathrm{~mm}, 3-4 \mathrm{~mm}, 7-10 \mathrm{~mm}$ ). Fourier transform infrared (FTIR), scanning electron microscope (SEM) and energy dispersive X-ray (EDX) analyses were performed to evaluate the morphological and structural changes upon pretreatment. Subsequently, the degradation of lignin via thermal treatment was determined by Klason's lignin analysis, as described by Sluiter and 
Hames [24]. Lignin decomposed over a wide range of temperatures [25]. Klason's lignin analysis is a direct method used to determine the lignin in biomass by hydrolyzing carbohydrates using concentrated acid, leaving lignin as a residue which can be determined via gravimetric measurement. This study is a promising platform for an industrially and economically feasible lignocellulosic pretreatment to enhance biofuel production.

\section{Materials and Methods}

\subsection{Preparation of Samples}

EFB samples were obtained from Palm Oil Mill Tawau (Tawau, Sabah, Malaysia). The samples were pre-shredded and sieved to collect fibers at desired particle sizes (1 mm, 3-4 mm, 7-10 mm). The samples were then kept at room temperature until further use.

\subsection{Thermal Pretreatment of EFB}

Prior to the thermal treatment, EFB samples were placed on aluminum foil and oven-dried at $60{ }^{\circ} \mathrm{C}$ overnight. Approximately $3 \mathrm{~g}$ of the oven-dried EFB samples were treated at different temperatures $\left(150{ }^{\circ} \mathrm{C}, 170{ }^{\circ} \mathrm{C}, 190^{\circ} \mathrm{C}\right.$ and $\left.210^{\circ} \mathrm{C}\right)$, durations $(30,60,90$ and $120 \mathrm{~min})$ and particle sizes $(1 \mathrm{~mm}, 3-4 \mathrm{~mm}$, 7-10 mm). Upon completion of the treatment, the heat was stopped, and the sample was allowed to cool down at an ambient temperature. The treated samples were collected and weighed before the characterization and lignin degradation analyses. The treatment with pressure was conducted inside a reactor with pressure set at 15 psi. The reactor was initially flushed with nitrogen.

\subsection{Characterization of EFB}

Observations on the morphological changes were carried out using an SEM (Hitachi S-3400 N, Hitachi High-Tech Science America, Inc., Los Angeles, CA, USA). The changes included the removal of silica compounds and other impurities on the EFB surface. EFB samples were mounted on the sampling holder using double-side adhesive tape and coated with gold before the morphological examination. The elemental analysis of the samples was determined using an SEM-energy dispersive X-ray (SEM-EDX) (Hitachi S-3400 N, USA). Fourier transform infrared (FTIR) (Agilents Technology Cary 630, Agilent Technologies, Inc., Santa Clara, CA, USA) was used to conduct the characterization of functional groups. The changes were observed by comparing the treated samples with the untreated counterparts.

\subsection{Determination of Lignin Degradation}

The lignin content in the pretreated samples was analyzed by using Klason's lignin analysis method [26]. Approximately $150 \mathrm{mg}$ of EFB was added into $3 \mathrm{~mL}$ of $72 \%$ sulfuric acid $\left(\mathrm{H}_{2} \mathrm{SO}_{4}\right)$, and incubated in a water bath at $30{ }^{\circ} \mathrm{C}$ for an hour. After incubation, $84 \mathrm{~mL}$ of distilled water was added and then autoclaved at $125^{\circ} \mathrm{C}$ for one hour. After cooling down at room temperature, the solid sample was separated from the solution through filtration using a filter paper. In total, $5 \mathrm{~mL}$ of the filtrate was mixed with $3 \% \mathrm{H}_{2} \mathrm{SO}_{4}$ before measuring the absorbance using a UV spectrophotometer (Shimadzu, Canby, OR, USA) at the $205 \mathrm{~nm}$ wavelength. The percentage of lignin degradation was determined using Equation (1).

$$
\text { Lignin Degradation }(\%)=\frac{\text { Lignin }(\text { untreated })-\text { Lignin }(\text { treated })}{\text { Lignin }(\text { untreated })} \times 100
$$




\section{Results}

\subsection{Morphological External Surface}

\subsubsection{Physical Appearance Observation}

Physical changes in biomass due to thermal treatment have been known to improve the enzymatic hydrolysis of cellulose by increasing the biomass pore size for enzyme penetration and decreasing its crystallinity and association with lignin [27]. Figure 1 shows the physical appearance of untreated EFB (Figure 1a,f), treated EFB at various temperatures $\left(150{ }^{\circ} \mathrm{C}, 170{ }^{\circ} \mathrm{C}, 190{ }^{\circ} \mathrm{C}\right.$ and $\left.210{ }^{\circ} \mathrm{C}\right)$ for 90 min under an inert atmosphere (Figure $1 \mathrm{~b}-\mathrm{e}$ ), and EFB treated under similar pretreatment conditions but in the presence of pressure (15 psi), as a comparative study (Figure $1 \mathrm{~g}-\mathrm{j}$ ). The color and morphological changes upon thermal treatment were observed and compared with the untreated counterpart.

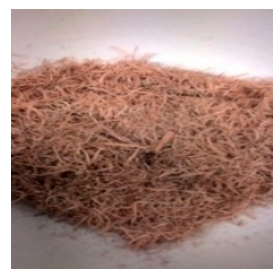

(a)

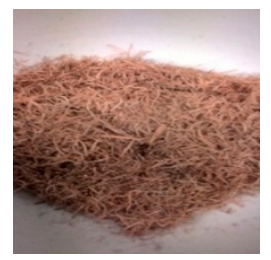

(f)

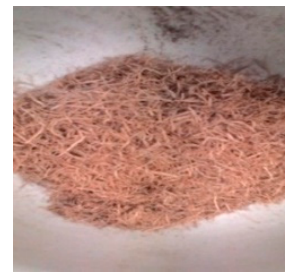

(b)

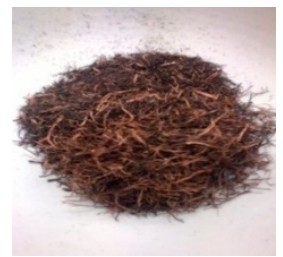

(g)

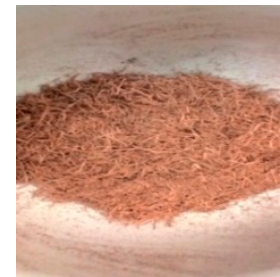

(c)

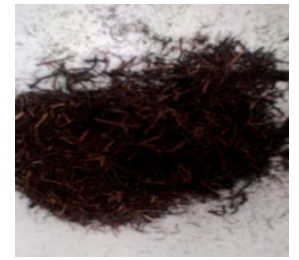

(h)

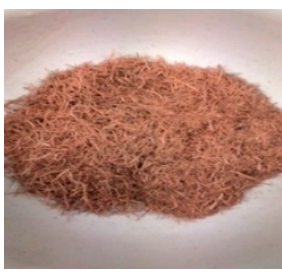

(d)

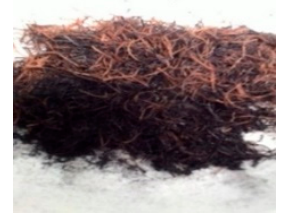

(i)

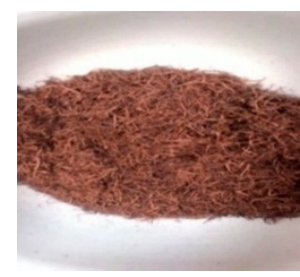

(e)

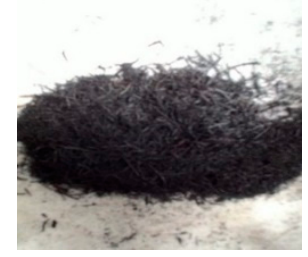

(j)

Figure 1. Physical appearance of untreated $\operatorname{EFB}(\mathbf{a}, \mathbf{f})$ and thermally pretreated $\operatorname{EFB}$ at $150{ }^{\circ} \mathrm{C}(\mathbf{b}, \mathbf{g})$, $170{ }^{\circ} \mathrm{C}(\mathbf{c}, \mathbf{h}), 190^{\circ} \mathrm{C}(\mathbf{d}, \mathbf{i})$ and $210^{\circ} \mathrm{C}(\mathbf{e}, \mathbf{j})$ for $90 \mathrm{~min}$. The top images $(\mathbf{b}-\mathbf{e})$ and bottom images $(\mathbf{f}-\mathbf{j})$ of samples were pretreated in the absence and presence of pressure (15 psi), respectively.

Observably, the samples became darker in color as the pretreatment temperature increased. A significant color change was observed when the highest pretreatment temperature $\left(210^{\circ} \mathrm{C}\right)$ was applied. It is important to note that smell, like 'burnt sugar', was generated during the treatment process. This observation was in agreement with a reported study wherein the smell was more evident at a higher temperature and longer duration of the thermal pretreatment [18]. The photochemical reaction of carbohydrate and lignin compounds in EFB might be responsible for the smell phenomenon that occurred with an increased temperature [28].

In the presence of pressure (Figure $1 \mathrm{f}-\mathrm{j}$ ), the impact on the color change was more remarkable. The EFB samples turned to a black color even at the lowest temperature $\left(150^{\circ} \mathrm{C}\right)$ and became ashes at the highest pretreatment temperature $\left(210^{\circ} \mathrm{C}\right)$. Aita and Kim [29] reported that the lignin structure would be modified at high temperatures and pressures by the melting, coagulation and reprecipitation of cellulose fibers. These resulted in the cellulose fibrils becoming more accessible to enzyme reactions. Although high pressures could increase the pore volume of cellulose and therefore its surface area, this study reveals that pressure could alter the EFB physical structures significantly. A reduction of total carbohydrate may occur due to the elimination of the waxy layer on the outer surface of the EFB structure [29]. Such physical changes should be kept minimal in the thermal treatment to prevent the degradation of hydrolyzable sugars. As such, pretreatment with moderate temperature and without additional pressure is preferable for an economical process, and importantly to preserve the fermentable sugars from being degraded. 


\subsubsection{SEM Observation}

The SEM images for the untreated and thermally treated EFB samples at different temperatures are presented in Figure 2. The structures of untreated EFB (Figure 2a) were smooth and rigid. The external wall exhibited ball-like structures embedded on the EFB structure, which are possibly the silica bodies described by Isroi and Cifriadi [30]. These round-shaped spiky silica bodies attached to circular craters are spread around the EFB strands. Bahrin and Baharuddin [18] reported that the amount of silica on the EFB surface was determined to be roughly $5 \%$. After the pretreatment process, a partial disruption on the EFB cell wall was observed (Figure $2 b-e$ ), where most of the silica bodies were removed. The removal of the external walls of EFB was attributed to lignin solubilization [20]. The impact was less significant at lower temperatures, as evidenced by the treated samples at $150{ }^{\circ} \mathrm{C}$ (Figure $2 \mathrm{~b}$ ) and $170^{\circ} \mathrm{C}$ (Figure 2c), whereat some of the silica bodies were still intact on the EFB's surface. A similar finding was also reported when superheated steam was employed at a temperature of around $140^{\circ} \mathrm{C}$ [18]. The findings indicate that a greater change on the surface morphology could be observed when higher temperatures are applied (Figure 2d,e). Most impurities on the EFB surface were also removed, making the surface smoother.

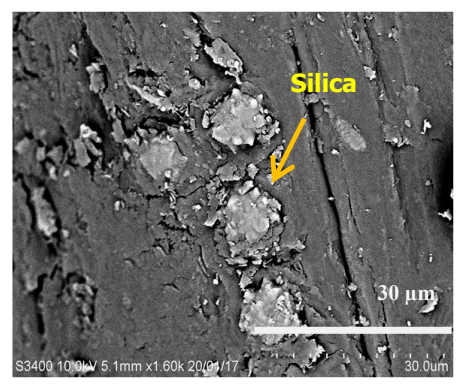

(a)

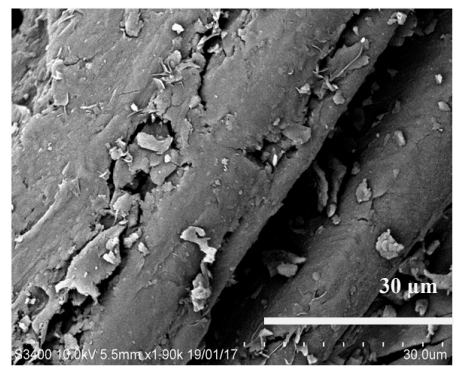

(d)

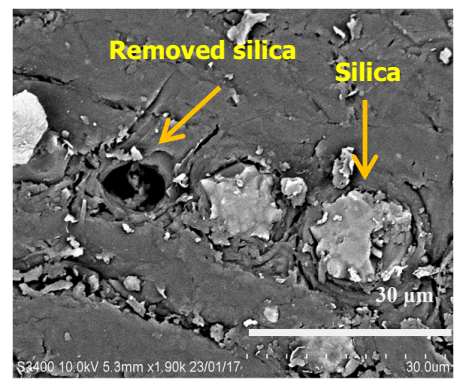

(b)

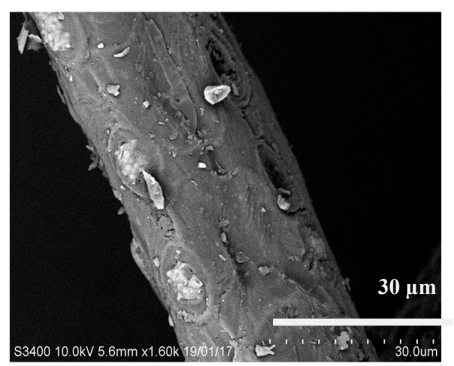

(e)

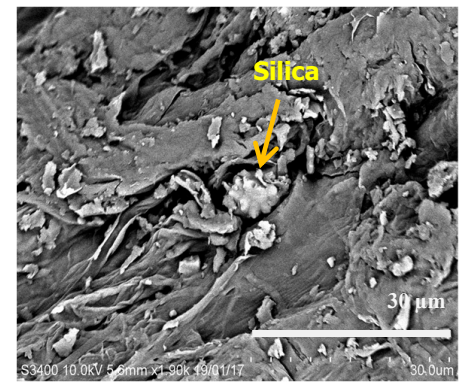

(c)

Figure 2. SEM micrograph of (a) untreated EFB and thermally treated EFB at (b) $150{ }^{\circ} \mathrm{C},(\mathbf{c}) 170{ }^{\circ} \mathrm{C}$, (d) $190{ }^{\circ} \mathrm{C}$ and (e) $210^{\circ} \mathrm{C}$ for $90 \mathrm{~min}$.

As revealed by these findings, sufficient energy was required to remove the embedded silica bodies. The thermal treatment above $170{ }^{\circ} \mathrm{C}$ was found to significantly alter the EFB surface. In a previous study, the silica bodies were dislodged using other extensive treatments, such as washing, hammering and crushing [30]. Silica is known as a chemical composition barrier in the EFB structure, as its removal facilitates the formation of pores that increase the surface area for enzyme accessibility [31]. The fraction of pores has also been reported to trigger enzymatic and microbial reactions, as it was thought to be effective in the swelling of the EFB structure [19].

The effect of particle size on EFB thermal treatment was also evaluated, as depicted in Figure 3. Pretreatment using smaller particle sizes contributed to a distinct change in the EFB's physical appearance. The silica bodies were found missing on the outer surfaces of the $1 \mathrm{~mm}$ and 3-4 mm treated EFB samples (Figure 3a,b), while treatment using the largest particle size of EFB showed most of the silica bodies remaining embedded, implying the EFB surface was less affected by the 
treatment (Figure 3c). These trends of observations are probably attributed to the surface area available for pretreatment. The smaller size of EFB provides a larger surface area to be exposed to the thermal reaction.

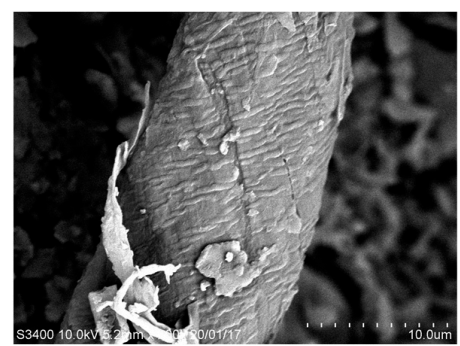

(a)

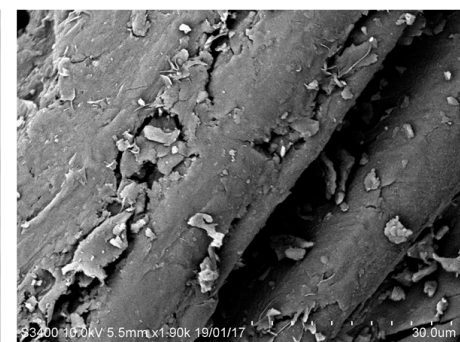

(b)

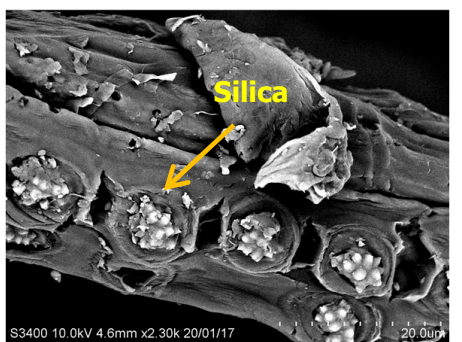

(c)

Figure 3. SEM micrograph of treated EFB using different particle size: (a) $1 \mathrm{~mm}$, (b) 3-4 mm, (c) 7-10 mm pretreated at $190^{\circ} \mathrm{C}$ for $90 \mathrm{~min}$.

\subsection{Chemical Compounds Analysis}

Figure 4 illustrates the results of elemental analysis as a function of particle size and pretreatment temperature. The elemental compounds found after EFB treatment were compared with the untreated properties to assess the changes during treatment. The untreated EFB majorly consisted of oxygen (32.09 wt. \%), followed by silicon ( $24.07 \mathrm{wt}$ \%) and carbon (17. $27 \mathrm{wt}$ \%). Other elements, including magnesium, kalium, calcium and niobium, made up about $24.07 \mathrm{wt}$ \% (Figure 4). After thermal treatment, the carbon rapidly increased from $17.27 \mathrm{wt}$ \% to above $60 \mathrm{wt} . \%$, while oxygen content slightly reduced, from $32.09 \mathrm{wt}$. \% to below $30 \mathrm{wt}$. \%. The decrease in the oxygen content after thermal treatment was likely due to the decomposition of the oxygenated bonds and the release of low molecular weight by-products containing $\mathrm{H}$ and $\mathrm{O}$ [32]. The most significant effect was observed in the treatments using $190^{\circ} \mathrm{C}$ and above. Silicon and other elements sharply decreased and became almost absent at this range of temperature, implying the decomposition of the compounds [33]. A decrease in calcium and magnesium was reported as the pyrolysis temperature was increased from 450 to $600{ }^{\circ} \mathrm{C}$, using hickory wood as the feedstock [26]. Some metals were also suggested to be volatile at high temperatures [34].

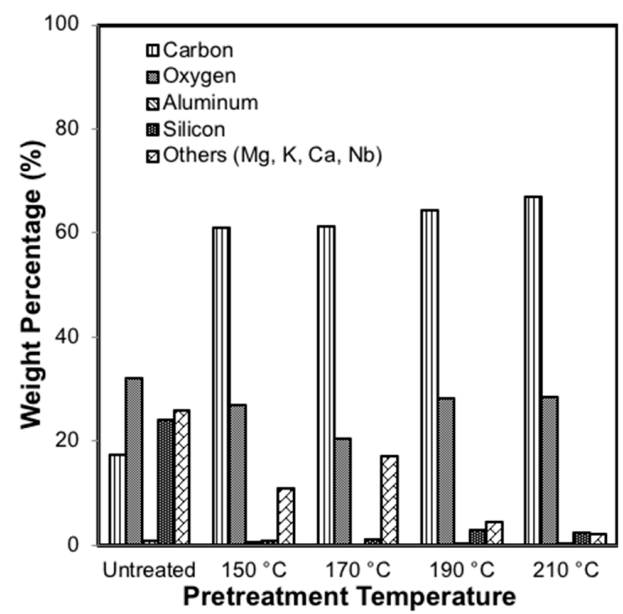

(a)

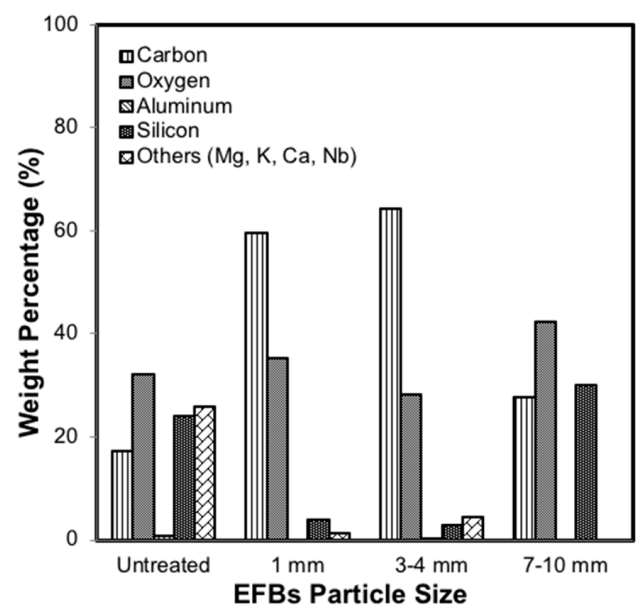

(b)

Figure 4. Profile of chemical elements that exist in untreated and treated EFB using different (a) pretreatment temperatures and (b) particle sizes of EFB.

The elemental composition of the treated EFB was also greatly affected by EFB particle size (Figure $4 \mathrm{~b}$ ). There were major increases in carbon after thermal pretreatment using the $1 \mathrm{~mm}$ and 
3-4 mm EFB sizes, of about 3.45-fold and 3.72-fold, respectively. Pretreatment using the largest particle size $(7-10 \mathrm{~mm})$, on the other hand, demonstrated an escalation of oxygen content of about 1.6-fold, similar to its carbon increment (1.3-fold). It is important to note that while silicon and other elements of the $1 \mathrm{~mm}$ and 3-4 mm EFB sizes were majorly decomposed after treatment, the silicon content remained approximately $30 \mathrm{wt}$. \% for the $7-10 \mathrm{~mm}$ sample. This result indicates that the volatile fractions removed were most likely attributed to the high surface area available for pretreatment.

\subsection{Changes on Chemical Functional Groups}

Fourier transformed infrared (FTIR) analysis was performed to evaluate the structural changes due to thermal treatment, as presented in Figure 5. The treated EFB demonstrated significant structural differences when compared with the untreated counterpart. A considerable number of absorption bands were found to have disappeared, while some were notably decreased. Greater changes were found on the samples pretreated using higher temperatures (Figure 5a), longer pretreatment times (Figure 5b) and smaller EFB particle sizes (Figure 5c). The peak at $1225 \mathrm{~nm}$ indicates the functional group for C-O from the guaiacyl ring in lignin [35], while the peak at $1445 \mathrm{~nm}$ indicates the stretching of (C-C) in the aromatic ring. Grube and Lin [36] also reported that both peaks are typical signals for the lignin component. The valent of $\mathrm{C}-\mathrm{O}, \mathrm{C}-\mathrm{C}$, and the deformation variations in the ring structures of $\mathrm{CH}_{2} \mathrm{OH}$ origin correspond to the band in the 950 to $1200 \mathrm{~cm}^{-1}$ region [18]. Meanwhile, the notable peaks at $550 \mathrm{~nm}$ resemble alkyl halide or halo compound $\mathrm{C}-\mathrm{Br}$ stretching with strong intensity. The reduction in peak intensity indicates the alteration of the functional groups present in the EFB structure. Bahrin and Baharuddin [18] explained that the disappearance of the absorptions might be associated with the decomposition of hemicellulose components in EFB during thermal treatment. It may be concluded through these FTIR findings that certain composition changes occurred after the samples underwent pretreatment.

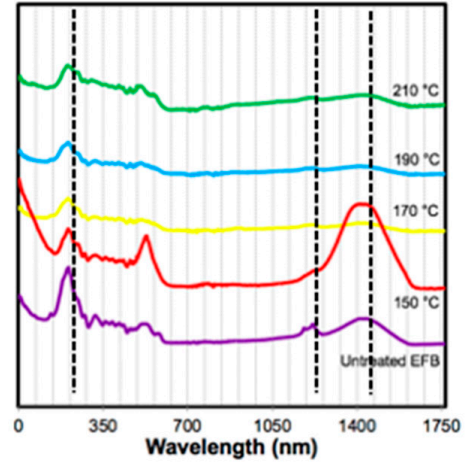

(a)

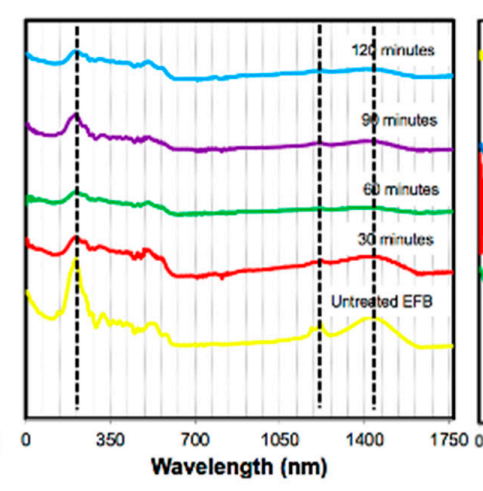

(b)

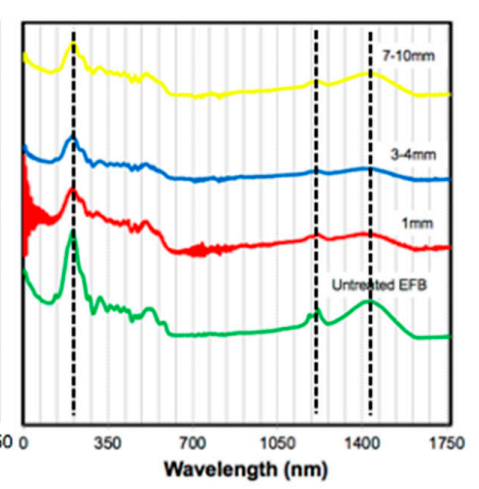

(c)

Figure 5. FTIR spectra of untreated and treated EFB using different (a) pretreatment temperatures, (b) pretreatment times and (c) particle sizes of EFB.

\subsection{Effect of Thermal Treatment on Lignin Degradation}

The lignin degradation profile of EFB pretreated using different temperatures (Figure 6a), durations (Figure 6b) and particle sizes (Figure 6c) was further evaluated. The lignin content was determined using Klason's lignin analysis [24]. It is a direct method that uses concentrated acid to hydrolyze carbohydrates present in the samples, leaving only lignin as the residue, which is then analyzed via gravimetric measurement. As Figure 6a indicates, smaller EFB sizes demonstrated a higher percentage of lignin degradation. The $1 \mathrm{~mm}$-sized EFB yielded lignin degradations that were about 1.2-fold and 2.2-fold higher than the pretreated samples using 3-4 mm and 7-10 $\mathrm{mm}$ sizes, respectively (Figure 6b). As the particle size reduced, the surface area available for pretreatment to 
take place on increased. In addition, a longer pretreatment time and higher temperature might be required to break down the physical structure of the larger EFB.

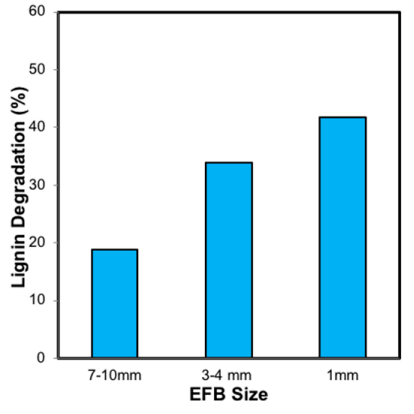

(a)

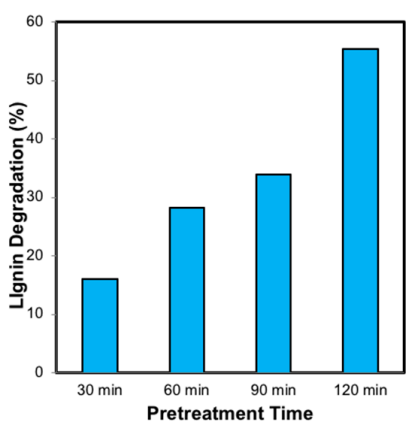

(b)

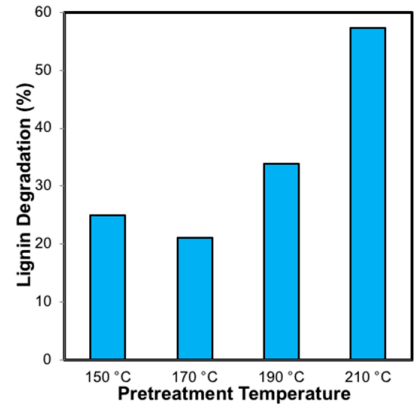

(c)

Figure 6. Profile of lignin degradation of the thermal pretreated EFB using different operating conditions. (a) Effect of EFB particle size on lignin degradation pretreated at $190^{\circ} \mathrm{C}$ for $90 \mathrm{~min}$. (b) Effect of time on lignin degradation pretreated at $190{ }^{\circ} \mathrm{C}$ using $1 \mathrm{~mm}$ EFB particle size. (c) Effect of temperature on lignin degradation pretreated for 90 min using $1 \mathrm{~mm}$ EFB particle size.

The findings in Figure $6 \mathrm{~b}$ demonstrate a consistent increase in the percentage of lignin degradation with the increase in the duration of pretreatment. Extending the pretreatment time to $120 \mathrm{~min}$ led to the highest lignin degradation, estimated at $56 \%$, when compared to the $16 \%$ achieved by the $30 \mathrm{~min}$ pretreatment. This agrees with the rule of thumb that a longer pretreatment duration provides sufficient time for a complete reaction to take place.

Figure $6 \mathrm{c}$ presents the effect of pretreatment temperature on lignin degradation. Thermal treatments at $150{ }^{\circ} \mathrm{C}$ and $170{ }^{\circ} \mathrm{C}$ yielded almost the same lignin degradation, of around $20-25 \%$. Increasing the temperature yielded a significant increase in lignin degradation. By using the highest temperature $\left(210^{\circ} \mathrm{C}\right)$, the yield remarkably improved, reaching almost $60 \%$ lignin degradation. Heat can disrupt the structural and physicochemical properties of biomass. Other factors that could influence the disruption are the heating rate and holding time [37]. At longer pretreatment times and higher temperatures, lignin could be degraded into smaller or more soluble fragments by the vigorous breaking of hydrogen bond and thus the decreasing amount of $\beta-\mathrm{O}-4$ linkages [38]. Nevertheless, at low temperatures, these fragments would be able to re-condense and rearrange themselves into other forms.

The thermal treatment in this study features a potential optimal method for lignin degradation in EFB structures under moderate conditions. Benchmarking the findings with previously reported studies, as shown in Table 1, the thermal treatment in this study shows a comparable or even greater lignin degradation. The pretreatment at $210{ }^{\circ} \mathrm{C}$ without the addition of chemicals or pressure resulted in the degradation of lignin at around $58 \%$. In addition, the carbohydrate components of EFB were also probably reduced. Bahrin and Baharuddin [18] reported reductions in cellulose and hemicelluloses from $71.3 \%$ to $63.7 \%$ after EFB superheated steam treatment at $210{ }^{\circ} \mathrm{C} / 60 \mathrm{~min}$. According to Tadesse and Luque [39], the pretreatment process of lignocellulose generally consists of rupturing the complex lignin seal and loosening the crystalline structure of cellulose.

Besides the selection of treatment methods, the type of biomass may also contribute to the performance of lignin removal. For instance, grass waste may not be as recalcitrant as EFB lignocelluloses, thus yielding a higher lignin degradation $(73.2 \%)$ via chemical treatment. Biological treatment using fungal strains, on the other hand, requires more days of treatment (25-42 days) than the thermal approach. Future research should be designed to assess the effectiveness of this thermal treatment in increasing the bioconversion of fermentable sugars into bioethanol from EFB. Detailed economic analysis also needs to be conducted as an important guideline for the financial feasibility of large-scale operations. 
Table 1. Comparison of the improvement in lignin degradation with previous studies related to lignocellulosic treatment using various treatment methods and different types of biomass.

\begin{tabular}{|c|c|c|c|c|}
\hline Treatment Method & Operating Conditions & Biomass & $\begin{array}{c}\text { Lignin Degradation } \\
(\%)\end{array}$ & Reference \\
\hline Chemical treatment & $\mathrm{NaOH}$ pretreatment supplemented with $\mathrm{H}_{2} \mathrm{O}_{2}$ & Grass waste & 73.2 & [40] \\
\hline Chemical treatment & $5.29 \% \mathrm{NaOH}, 1 \% \mathrm{H}_{2} \mathrm{O}_{2}$ at $20^{\circ} \mathrm{C}$ & Rice husk & 59.85 & [41] \\
\hline Physical treatment & Heating at $210^{\circ} \mathrm{C}$ for $90 \mathrm{~min}$ at inert atmosphere & Oil palm EFB & 58 & This study \\
\hline Biological treatment & Fungal strain (Chaetomium globosporum) at $36^{\circ} \mathrm{C}$ for 31 days & Wheat straw & 45 & [42] \\
\hline Chemo-physical treatment & $40 \mathrm{~min}$ treatment using high voltage electrical discharge treatment and $\mathrm{NaOH}(0.125-0.5 \mathrm{M})$ at $60-90^{\circ} \mathrm{C}$ & Rapeseed straw & 42.3 & [43] \\
\hline Biological treatment & Fungal strain (Pleurotus ostreatus) at $28^{\circ} \mathrm{C}$ for 42 days & Pearl millet straw & 30 & [44] \\
\hline Chemical treatment & $2 \%$ alkaline peroxide at $100{ }^{\circ} \mathrm{C}$ & Wood powders & 28.8 & [45] \\
\hline Chemical treatment & ChCl:Urea (1:2) at $80^{\circ} \mathrm{C}$ for $15 \mathrm{~h}$ & Corncob & 27.1 & [46] \\
\hline Biological treatment & Fungal strain (Pleurotus ostreatus)at $28^{\circ} \mathrm{C}$ for 42 days & Wheat straw & 21 & [44] \\
\hline Biological treatment & Fungal strain (Coriolus versicolor)at $30^{\circ} \mathrm{C}$ for 25 days & Paddy straw & 19 & [47] \\
\hline
\end{tabular}




\section{Conclusions}

The effectiveness of the thermal pretreatment of the oil palm empty fruit bunch (EFB) for the removal of lignin was investigated in this study. The processing parameters, including EFB particle size, the duration of treatment and the temperature, were found to play vital roles in enhancing lignin degradation. Morphological observations revealed significant changes in the physicochemical structure of EFB upon thermal treatment. Characterization studies using SEM, EDX and FTIR analyses indicated the removal of silica bodies and other impurities, besides changes in elemental content and chemical functional groups. Nevertheless, applying pressure along with an elevated treatment temperature caused undesirable damages in the physical structure of EFB, and possibly the fermentable sugars. Smaller EFB particle sizes $(1 \mathrm{~mm})$, longer durations $(120 \mathrm{~min})$ and higher temperatures $\left(210^{\circ} \mathrm{C}\right)$ were found to be the optimal conditions for thermal treatment, yielding the highest lignin degradation, estimated at $58 \%$. The findings of this study reveal that thermal pretreatment is promising in enhancing lignin degradation, which may be beneficial in improving enzyme accessibility during fermentation and may contribute to setting up a solid foundation for biofuel production from biomass

Author Contributions: Conceptualization, C.M.O., M.M.; formal analysis and investigation, I.N.M.; writing_original draft preparation, I.N.M.; writing—-review and editing, M.M.; supervision, C.M.O., M.M.; project administration and funding acquisition, C.M.O. All authors have read and agreed to the published version of the manuscript.

Funding: The international collaborative research grant scheme GL00139 with Autodisplay Biotech GmBH, Germany: Saccharification of Oil Palm Empty Fruit Bunch using Autodisplay Cells.

Acknowledgments: The authors acknowledge the funding from research grant scheme (GL00139) Autodisplay Biotech GmBH, Germany.

Conflicts of Interest: The authors declare no conflict of interest.

\section{References}

1. Nambiappan, B.; Ismail, A.; Hashim, N.; Ismail, N.; Shahari, D.N.; Idris, N.A.N.; Omar, N.; Salleh, K.M.; Hassan, N.A.M.; Kushairi, A. Malaysia: 100 Years of Resilient Palm Oil Economic Performance. J. Oil Palm Res. 2018, 30, 13-25. [CrossRef]

2. Karunakaran, V.; Abd-Talib, N.; Yong, T.-L.K. Lignin from oil palm empty fruit bunches (EFB) under subcritical phenol conditions as a precursor for carbon fiber production. Mater. Today Proc. 2020, in press. [CrossRef]

3. Ali, M.D.M.; Tamunaidu, P.; Aslan, A.K.H.N.; Morad, N.A.; Sugiura, N.; Goto, M.; Zhang, Z. Hydrothermal pre-treatment of oil palm empty fruit bunch into fermentable sugars. IOP Conf. Ser. Earth Environ. Sci. 2016, $36,012042$.

4. Roslan, R.; Zakaria, S.; Chia, C.H.; Boehm, R.; Laborie, M.-P. Physico-mechanical properties of resol phenolic adhesives derived from liquefaction of oil palm empty fruit bunch fibres, Industrial Crops and Products. Ind. Crop. Prod. 2014, 62, 119-124. [CrossRef]

5. Krishnan, Y.; Bong, C.P.C.; Azman, N.F.; Zakaria, Z.; Othman, N.A.; Abdullah, N.; Ho, C.S.; Lee, C.T.; Hansen, S.B.; Hara, H. Co-composting of palm empty fruit bunch and palm oil mill effluent: Microbial diversity and potential mitigation of greenhouse gas emission. J. Clean. Prod. 2017, 146, 94-100. [CrossRef]

6. Sukiran, M.A.; Abnisa, F.; Daud, W.M.A.W.; Bakar, N.A.; Loh, S.K. A review of torrefaction of oil palm solid wastes for biofuel production. Energy Convers. Manag. 2017, 149, 101-120. [CrossRef]

7. Palamae, S.; Dechatiwongse, P.; Choorit, W.; Chisti, Y.; Prasertsan, P. Cellulose and hemicellulose recovery from oil palm empty fruit bunch (EFB) fibers and production of sugars from the fibers. Carbohydr. Polym. 2017, 155, 491-497. [CrossRef] [PubMed]

8. Rambo, M.K.D.; Schmidt, F.L.; Ferreira, M.M.C. Analysis of the lignocellulosic components of biomass residues for biorefinery opportunities. Talanta 2015, 144, 696-703. [CrossRef]

9. Chauhan, P.S. Role of various bacterial enzymes in complete depolymerization of lignin: A review. Biocatal. Agric. Biotechnol. 2020, 23, 101498. [CrossRef]

10. Datta, R.; Kelkar, A.; Baraniya, D.; Molaei, A.; Moulick, A.; Meena, R.S.; Formanek, P. Enzymatic degradation of lignin in soil: A review. Sustainability 2017, 9, 11636. [CrossRef] 
11. Sarip, H.; Hossain, M.S.; Azemi, M.; Allaf, K. A Review of the Thermal Pretreatment of Lignocellulosic Biomass towards Glucose Production: Autohydrolysis with DIC Technology. BioResources 2016, 11, 10625-10653.

12. Aftab, M.N.; Iqbal, I.; Riaz, F.; Karadag, A.; Tabatabaei, M. Different pretreatment methods of lignocellulosic biomass for use in biofuel production. In Biomass for Bioenergy-Recent Trends and Future Challenges; IntechOpen: London, UK, 2019.

13. Peng, F.; Peng, P.; Xu, F.; Sun, R.-C. Fractional purification and bioconversion of hemicelluloses. Biotechnol. Adv. 2012, 30, 879-903. [CrossRef] [PubMed]

14. Kang, S.; Bu, D.; Xue, L.; Wang, Q.; Jiang, M. Degradation of lignin catalyzed by nanochannels solid acids in ionic liquid. Polym. Degrad. Stab. 2019, 166, 1-7. [CrossRef]

15. Tolesa, L.D.; Gupta, B.S.; Tiwikrama, A.H.; Wu, Y.-C.; Lee, M.-J. Alkali lignin degradation with aqueous ammonium-based ionic liquid solutions. J. Clean. Prod. 2020, 258, 120724. [CrossRef]

16. Schneider, W.D.H.; Fontana, R.C.; Baudel, H.M.; Siqueira, F.G.d.; Jorge Rencoret, A.G.; Eugenio, L.I.d.; Prieto, A.; Martínez, M.J.; Martínez, Á.T.; Dillon, A.J.P.; et al. Lignin degradation and detoxification of eucalyptus wastes by on-site manufacturing fungal enzymes to enhance second-generation ethanol yield. Appl. Energy 2020, 26215, 114493. [CrossRef]

17. de Gonzalo, G.; Colpa, D.I.; Habib, M.H.; Fraaije, M.W. Bacterial enzymes involved in lignin degradation. J. Biotechnol. 2016, 236, 110-119. [CrossRef]

18. Bahrin, E.K.; Baharuddin, A.S.; Ibrahim, M.F.; Razak, M.N.A.; Sulaiman, A.; Abd-Aziz, S.; Hassan, M.A.; Shirai, Y.; Nishida, H. Physicochemical property changes and enzymatic hydrolysis enhancement of oil palm empty fruit bunches treated with superheated steam. BioResourse 2012, 7, 1784-1801.

19. Shamsudin, S.; Shah, U.K.M.; Zainudin, H.; Abd Aziz, S.; Kamal, S.M.M.; Shirai, Y.; Hassan, M.A. Effect of steam pretreatment on oil palm empty fruit bunch for the production of sugars. Biomass Bioenergy 2012, 36, 280-288. [CrossRef]

20. Chin, S.X.; Chia, C.H.; Zakaria, S.; Fang, Z.; Ahmad, S. Ball milling pretreatment and diluted acid hydrolysis of oil palm empty fruit bunch (EFB) fibres for the production of levulinic acid. J. Taiwan Inst. Chem. Eng. 2015, 52, 85-92. [CrossRef]

21. Santanaraj, J.; Sajab, M.S.; Mohammad, A.W.; Harun, S.; Chia, C.H.; Zakaria, S.; Kaco, H. Enhanced delignification of oil palm empty fruit bunch fibers with in situ Fenton-oxidation. Bioresources 2017, 12, 5223-5235. [CrossRef]

22. Chruściel, J.J.; Leśniak, E. Modification of epoxy resins with functional silanes, polysiloxanes, silsesquioxanes, silica and silicates. Prog. Polym. Sci. 2015, 41, 67-121. [CrossRef]

23. Laurichesse, S.; Avérous, L. Chemical modification of lignins: Towards biobased polymers. Prog. Polym. Sci. 2014, 39, 1266-1290. [CrossRef]

24. Sluiter, A.; Hames, B.; Ruiz, R.; Scarlata, C.; Sluiter, J.; Templeton, D.; Crocker, D. Determination of Structural Carbohydrates and Lignin in Biomass. Lab. Anal. Proced. 2012, 1617, 1-16.

25. Yang, H.; Yan, R.; Chen, H.; Lee, D.H.; Zheng, C. Characteristics of hemicellulose, cellulose and lignin pyrolysis. Fuel 2007, 86, 1781-1788. [CrossRef]

26. Sun, Y.; Gao, B.; Yao, Y.; Fang, J.; Zhang, M.; Zhou, Y.; Chen, H.; Yang, L. Effects of feedstock type, production method, and pyrolysis temperature on biochar and hydrochar properties. Chem. Eng. J. 2014, 240, 574-578. [CrossRef]

27. Cybulska, I.; Chaturvedi, T.; Thomsen, M.H. Lignocellulosic Thermochemical Pretreatment Processes; Bastidas-Oyanedel, J.R., Schmidt, J., Eds.; Springer International Publishing: Cham, Switzerland, 2019; p. 763.

28. Bledzki, A.K.; Mamun, A.A.; Volk, J. Physical, chemical and surface properties of wheat husk, rye husk and soft wood and their polypropylene composites. Compos. Part A Appl. Sci. Manuf. 2010, 41, 480-488. [CrossRef]

29. Aita, G.A.; Kim, M. Pretreatment technologies for the conversion of lignocellulosic materials to bioethanol. In: Sustainability of the Sugar and Sugar-Ethanol Industries. Am. Chem. Soc. 2010, 117-145. [CrossRef]

30. Isroi, C.A.; Panji, T.; Wibowo, N.A.; Syamsu, K. Bioplastic production from cellulose of oil palm empty fruit bunch. IOP Conf. Ser. Earth Environ. Sci. 2017, 65, 012011. [CrossRef]

31. Ariffin, H.; Hassan, M.A.; Kalsom, M.S.U.; Abdullah, N.; Shirai, Y. Effect of physical, chemical and thermal pretreatments on the enzymatic hydrolysis of oil palm empty fruit bunch. J. Trop. Agric. Food Sci. 2008, 36, $1-10$. 
32. Suliman, W.; Harsh, J.B.; Abu-Lail, N.I.; Fortuna, A.-M.; Dallmeyer, I.; Garcia-Perez, M. Influence of feedstock source and pyrolysis temperature on biochar bulk and surface properties. Biomass Bioenergy 2016, 84, 37-48. [CrossRef]

33. Zhao, S.X.; Ta, N.; Wang, X.D. Effect of Temperature on the Structural and Physicochemical Properties of Biochar with Apple Tree Branches as Feedstock Material. Energies 2017, 10, 1293. [CrossRef]

34. Pituello, C.; Francioso, O.; Simonetti, G. Characterization of chemical-physical, structural and morphological properties of biochars from biowastes produced at different temperatures. J. Soils Sediments 2015, 15, 792-804. [CrossRef]

35. Zulkefli, S.; Abdulmalek, E.; Rahman, M.B.A. Pretreatment of oil palm trunk in deep eutectic solvent and optimization of enzymatic hydrolysis of pretreated oil palm trunk. Renew. Energy 2017, 107, 36-41. [CrossRef]

36. Grube, M.; Lin, J.G.; Lee, P.H.; Kokorevicha, S. Evaluation of sewage sludge-based compost by FT-IR spectroscopy. Geoderma 2006, 130, 324-333. [CrossRef]

37. Guizani, C.; Jeguirim, M.; Valin, S.; Limousy, L.; Salvador, S. Biomass Chars: The Effects of Pyrolysis Conditions on Their Morphology, Structure, Chemical Properties and Reactivity. Energies 2017, 10, 796. [CrossRef]

38. Pu, Y.; Hu, F.; Huang, F.; Davison, B.; Ragauskas, A. Assessing the molecular structure basis for biomass recalcitrance during dilute acid and hydrothermal pretreatments. Biotechnol. Biofuels 2013, 6, 15. [CrossRef]

39. Tadesse, H.; Luque, R. Advances on biomass pretreatment using ionic liquids: An overview. Energy Environ. Sci. 2011, 4, 3913. [CrossRef]

40. Yan, X.; Cheng, J.-R.; Wang, Y.-T.; Zhu, M.-J. Enhanced lignin removal and enzymolysis efficiency of grass waste by hydrogen peroxide synergized dilute alkali pretreatment. Bioresour. Technol. 2020, 301, 122756. [CrossRef]

41. Bazargan, A.; Wang, Z.; Barford, J.P.; Saleem, J.; McKay, G. Optimization of the removal of lignin and silica from rice husks with alkaline peroxide. J. Clean. Prod. 2020, 260, 120848. [CrossRef]

42. Yadav, M.; Singh, A.; Balan, V.; Pareek, N.; Vivekanand, V. Biological treatment of lignocellulosic biomass by Chaetomium globosporum: Process derivation and improved biogas production. Int. J. Biol. Macromol. 2019, 128, 176-183. [CrossRef]

43. Brahim, M.; Kantar, S.E.; Boussetta, N.; Grimi, N.; Brosse, N.; Vorobiev, E. Delignification of rapeseed straw using innovative chemo-physical pretreatments. Biomass Bioenergy 2016, 95, 92-98. [CrossRef]

44. Yadav, M.; Paritosh, K.; Pareek, N.; Vivekanand, V. Coupled treatment of lignocellulosic agricultural residues for augmented biomethanation. J. Clean. Prod. 2019, 213, 75-88. [CrossRef]

45. Baksi, S.; Sarkar, U.; Saha, S.; Ball, A.K.; Kuniyal, J.C.; Wentzel, A.; Birgen, C.; Preisig, H.A.; Wittgens, B.; Markussen, S. Studies on delignification and inhibitory enzyme kinetics of alkaline peroxide pre-treated pine and deodar saw dust. Chem. Eng. Process. Process Intensif. 2019, 143, 107607. [CrossRef]

46. Procentese, A.; Johnson, E.; Orr, V.; Campanile, A.G.; Wood, J.A.; Marzocchella, A.; Rehmann, L. Deep eutectic solvent pretreatment and subsequent saccharification of corncob. Bioresour. Technol. 2015, 192, 31-36. [CrossRef]

47. Phutela, U.G.; Sahni, N.; Sooc, S.S. Fungal degradation of paddy straw for enhancing biogas production. Indian J. Sci. Technol. 2011, 4, 660-665. [CrossRef]

Publisher's Note: MDPI stays neutral with regard to jurisdictional claims in published maps and institutional affiliations.

(C) 2020 by the authors. Licensee MDPI, Basel, Switzerland. This article is an open access article distributed under the terms and conditions of the Creative Commons Attribution (CC BY) license (http://creativecommons.org/licenses/by/4.0/). 